\title{
STRUCTURE OF MONEY ATTITUDES OF SMALL INDIGENOUS PEOPLES OF THE RUSSIAN ARCTIC (ON THE SAMPLE OF NENETS)
}

\author{
Olga Deyneka ${ }^{1}$, Ekaterina Zabelina ${ }^{2}$, Svetlana Kurnosova ${ }^{2}$, \& Marina Lukmanova $^{3}$ \\ ${ }^{I}$ Department of Political Psychology, Saint Petersburg State University (Russia) \\ ${ }^{2}$ Department of Psychology and Pedagogics, Chelyabinsk State University (Russia) \\ ${ }^{3}$ Department of Economics and Management, Rudny Industrial Institute (Kazakhstan)
}

\begin{abstract}
Negative effects of globalization are visible in the most remote parts of our planet today including human life in the Arctic. Perhaps, economic changes are the most painful for the small indigenous peoples of the North. The active development of the fuel and energy sector causing environmental problems limits the opportunities for traditional farming and creates a need to change the economic behavior strategies of the indigenous peoples of the North. However, this particular behavior including attitude towards money has not been sufficiently studied. Money attitudes were studied $(\mathrm{N}=75)$ using the Money Beliefs and Behavior Scale (Furnham, 1984). The results of the factor analysis have showed a more fractional structure than in Furnham's studies $(1984,2014)$ indicating a complex and ambiguous (more diverse) picture of the reflection of money in the economic mind of northern peoples. Nine factors were identified and supported by strong correlation links: money as power, money as an indicator in social comparison, money as evil, the factor of respect for money, factor of money fetishism, factor of restrictive behavior, and factor of financial control, factor of financial anxiety, factor of financial success or failure. Despite a large number of factors, the main trends of money attitudes of small indigenous peoples of the Russian Arctic can be observed. They do not put money first in their values, do not use them as a tool of influence on other people, they respect those who know how to save money and do not spend it in vain. At the same time, there is a place for financial anxiety and pessimism, negative feelings related to money. The results should be taken into account in the program for the transformation of the economic behavior of the indigenous peoples of the Russian Arctic.
\end{abstract}

Keywords: Money attitudes, small indigenous peoples, economic mind, Russian Arctic, economic behavior.

\section{Introduction}

These days the effects of globalization are noticeable in the most remote corners of our planet including the changes in human life in the Arctic. Perhaps, changes in the economy were the most painful for the indigenous peoples of the North. The active development of the fuel and energy complex causing environmental problems limits the possibilities of traditional farming and reveals the need to change the strategies for the economic behavior of the indigenous peoples of the northern territories (Detter, 2017; Pavlenko et al., 2019; Sukneva, 2010 et al.). At the same time, the economic behavior of the indigenous peoples of the Russian Arctic, including their attitude to money, has not been studied enough.

The previous pilot study on the material of the Nenets youth (Zabelina, Kurnosova, 2018) revealed contradictions in attitude to money in this sample. On the one hand, the young people are less rational, naiver in dealing with their personal finances than their peers from the southeastern part of the country. For example, they are willing to participate in lotteries, and borrow money easier. Additionally, they do not like to count and plan their money accurately. On the other hand, the Nenets youth perceive money as something stable that can be relied upon, and, at the same time, associated with negative emotions. Perhaps, due to the revealed contradictions in the economic consciousness, the young Nenets subconsciously seek to get rid of money. They can use money as a tool in building relationships. Perhaps, the young people of this group do not completely separate the economic and personal sphere (Zabelina, Kurnosova, 2018). These trends highlight the risks of adaptation of the young Nenets to modern economic realities and are confirmed in other studies (Lusan et al., 2019). 
The revealed contradictions initiated this study, the purpose of which is to identify the structure of the attitude towards money among representatives of the indigenous peoples of the Russian Arctic, in particular, on the example of the Nenets.

\section{Method and sample}

Attitude to money was studied using A. Furnham's questionnaire "Money Beliefs and Behavior Scale" in the adaptation of O.S. Deineka (1999). Furnham was the first who proposed to explore money attitudes through the multifactorial questionnaire instead of using standardized techniques (Furnham, 1984) because of the flexibility that characterizes attitudes. The questionnaire consists of 45 items.

The study involved 75 people - representatives of the Nenets nationality aged 17 to 73 years (average age 28.6) living in the Yamal-Nenets Autonomous District (Aksarka village, Yar-Sale village) and the Nenets Autonomous District (Naryan-Mar city, Nes village, Krasnoye village). The form of the questionnaire was presented to the respondents in hard copy during the Reindeer Breeder Day celebration. The respondents 'behavior, the clarification questions they asked, and the time of completion were fixed (the average time for filling the questionnaire was 20 minutes).

To substantiate the structure of money attitudes of the Nenets, an exploratory factor analysis was performed based on the method of principal components with Varimax rotation. When processing the data, a statistical package SPSS 24.0 was used, including the structural equation software IBM SPSS AMOS 22. (IBM Corporation, Armonk, NY, USA).

\section{Results}

A factor analysis of the questionnaires made it possible to identify 9 factors in the structure of the Nenets' monetary attitudes supported by strong correlations that reflect the main trends in their attitude to money.

The first factor, "Money - power," includes various ways of influencing people by dint of money (in competition, in friendship and love, through demonstrative behavior and play). According to the descriptive statistics, the respondents mostly deny manifestations of financial behavior of this type. This factor included with a negative sign the aggregate opinions of respondents on the following statements:

"I often use money to influence rivals or enemies";

"I usually feel better than those who have less money";

"I think money is the only thing I can rely on";

"I play lotteries";

"Sometimes I buy things I don't need to impress my friends";

"Questions about my personal money bother or annoy me".

It can be assumed that money is not an instrument of influence on other people for the Nenets or a means of achieving goals in personal relationships. In addition, money is not a priority in the value system of these peoples, nor is it a matter of concern or evident care.

The second factor, "Money as an indicator in social comparison" (envy, pleasure in spending) combines the commonality of opinion (also with a negative sign) according to the following statements:

"I do not conceal from others the amount of money I have";

"I feel worse than those who have more money than me";

"My financial situation is worse than most of my friends think";

"I often leave small change to the seller";

"It is a pleasure for me to spend money";

"Most of my friends have more money than me".

Negative values of these statements may indicate that the financial situation of the representatives of the indigenous peoples of the Russian Arctic is neither a subject of demonstration for other people nor a secret. They are not inclined to compare their financial status with the status of other people from their environment, the envy of money is also not typical for them.

The third factor of respect for money (ability to save) includes a respect for the ability to save money, not to waste money, accuracy in dealing with money and thereby to increase one's financial well-being. At the same time, this factor reflects the fact that money is not the main value in the lives of these peoples, there are more important things, such as helping another person in need, or the quality and reliability of the goods or services purchased.

"I am proud of my ability to save money";

"My financial situation is better than most of my friends think";

"When shopping, I primarily think about the price (with a negative sign)";

"I give alms"; 
"I lay out the money in my wallet neatly in order of increasing value".

The fourth factor combines the idea of oniomania with contempt for money (or "Money is evil"). This factor includes controversial but generally negative opinions about money. On the one hand, this is an irrational desire to spend money, a lack of readiness to clearly realize one's financial situation. On the other hand, this factor reflects negative feelings associated with money - contempt, expectations of deception, anxiety, etc.

"I always know how much I have saved (with a negative sign)";

"If I have any amount of money, I feel uncomfortable until I spend it";

"I despise money and those who possess it";

"I feel cheated if I pay for something more than others";

"I think about money more often than others".

The fifth is the "Factor of fetishization of money". According to this factor, money for the representatives of the indigenous peoples is a symbol of freedom, a force that can solve all human problems. However, the Nenets do not believe that the presence of money is an indicator of one's moral qualities, and they think that most people share this opinion.

"In our country, a person is judged by the amount of money he has (with a negative sign)";

"I feel freer when I have money";

"The best gift is money";

"I strongly believe that money can solve all my problems".

The sixth factor - the "Factor of restrictive behavior" - reflects the presence of psychological attitudes, mechanisms that restrain monetary spending, among representatives of the indigenous peoples of the North.

"Even if I have a lot of money, I feel guilty spending money";

"I find it difficult to make decisions about spending money, regardless of their amount";

"I like to count money".

The seventh factor - the "Factor of financial control" - indicates the need for a clear, consistent calculation of one's funds and the control of savings, as well as an careful attitude to money.

"I always know how much I have accumulated"

"I keep track of my expenses and income"

"I always know exactly how much money I have with me".

"I lay out the money in my wallet neatly in order of increasing value".

The eighth factor is the "Factor of financial anxiety". This factor also reflects a careful attitude to money and focus on them, as well as the expectation of a financial failure in the future, financial pessimism.

"I carefully examine the design of notes and coins";

"I always recount change";

"I am saving money for a rainy day".

The eighth factor like the sixth one is essentially a reflection of the financial anxiety of the respondents.

The ninth factor is the "Factor of financial success / failure". The core of this factor is the connection of earnings with the abilities and efforts of a person. Lack of confidence in this connection leads to failure in financial affairs, inability to resist their own greed.

"I believe that people's earnings depend on their abilities and efforts (with a negative sign)";

"My financial situation is worse than most of my friends think";

"I often buy unnecessary things only because the price of them is reduced".

\section{Discussion}

The results of factor analysis showed a more fragmented structure than in the studies of Furnham (Furnham A., 1984), which indicates a complex and ambiguous (more diverse) picture of the reflection of money among representatives of the northern peoples. Other studies in the Russian sample also show a more holistic structure of monetary attitudes, consisting of five main factors that indicate an integrative assessment of the attitude to money, positive or negative (Semenov, 2010)

Despite the large number of factors in the structure, one can see the main trends in the attitude to money among the representatives of the indigenous peoples of the Russian Arctic. They do not put money in the first place in their lives, they are not inclined to use it as an instrument of influence on other people, they respect those who know how to save money and do not waste money in vain. At the same time, the representatives demonstrate financial anxiety and pessimism, negative feelings associated with money (contempt, expectations of fraud, anxiety), the desire to quickly part with money. 
The study proves the thesis that the influence of the factor based on the social class overlaps the influence of the level of income on the attitude to money (Deineka, 1999). The data obtained also agree well with the conclusions about the tendency of the indigenous peoples of the Arctic zone to passive, safe, low-risk financial strategies (Lusan et al., 2019), possibly due to increased financial anxiety.

\section{Conclusions}

The formulated conclusions about the diverse and contradictory structure of the attitude to money among the indigenous peoples of the Russian Federation on the example of the Nenets indicate alarming factors in terms of the effective economic behavior of these peoples in the changing economic conditions in the Arctic.

The main limitation of the study is associated with a small sample size, which can be explained by the difficulties in the data collection (difficult accessibility of nomadic peoples). Nevertheless, the surveyed sample is representative and includes the respondents varying in age, gender, and socio-demographic characteristics.

\section{Acknowledgments}

The reported study was funded by the RFBR under Research Project No. 19-013-00394 A.

\section{References}

Detter G.F. (2017). The Economy of the Reindeer Husbandry of Yamal: Problems and Opportunities // Scientific Bulletin of the Yamal-Nenets Autonomous District. № 4 (97). C. 4-16.

Deyneka, O.S. (1999). Ekonomicheskaya psihologiya: social'no-politicheskie problemy [Economical psychology: social-and-political problems], Saint Petersburg: SPbGU (In Russian)

Furnham, A. (1984). Many sides of the coin. Personality and Individual Differences. 5, 501-510

Luzan, V.S., Koptseva, N.P., Zabelina, E.V., Kurnosova, S.A., Trushina, I.A. (2019). The Structure of Economic Attitudes of the Youth - Representatives of the Indigenous Small-Numbered Peoples of the Arctic Zone of the Russian Federation: Results of a Pilot Study. Journal of Siberian Federal University. Humanities \& Social Sciences, 7 (12), 1146-1162

Pavlenko V.I., Petrov A., Kutsenko S.Yu., Detter G.F. (2019). Indigenous peoples of the Russian Arctic (problems and development prospects). Human Ecology, 1, 26-33.

Semenov, M.Y. (2010). Methodology for Assessing Monetary Relations Among Schoolchildren // Omsk Scientific Bulletin, 5 (91), 137-139.

Sukneva, S.A. (2010). The Demographic Potential of the Development of the Population of the Northern Region. Novosibirsk: Science.

The portal of psychological publications PsyJournals.ru - https://psyjournals.ru/authors/63537.shtml [Mikhail Semenov]

Zabelina E.V., Kurnosova S.A. (2018). Features of Economic Consciousness of Representatives of Indigenous Peoples of the Arctic Zone: Results of a Pilot Study of Youth. Petersburg Psychological Journal, 23, 54-68. 